\title{
Analysis of Accounting Conservatism on Accounting Policy Post-Implementation of International Financial Reporting Standard
}

\author{
Nurzi Sebrina ${ }^{1}$, Salma Taqwa ${ }^{2}$ \\ 1Universitas Negeri Padang, Padang, Indonesia, $\triangle$ nurzisebrina@gmail.com \\ ${ }^{2}$ Universitas Negeri Padang, Padang, Indonesia, $\bowtie$ salmataqwa@gmail.com
}

\begin{abstract}
The study aims to examine the conservatism of accounting policies after convergence to IFRS in the financial reporting of Indonesia. The study was conducted with the population of manufacturing companies listed in Indonesia Stock Exchange. Samples were determined by purposive sampling method, obtained a sample of 75 firms with 8 years of observation ( 20082015). Tests using a panel of data and there are 600-year-firm observations, where data is divided into two periods: before and after IFRS. The analysis using Basu Model (1997) was developed by Ismail and Elbolok (2011). The model to examine conditional and unconditional conservatism. Additionally, conducted the negative earnings response coefficient models (Basu, 1997, which was modified by Ball and Shivakumar, 2005, and Ruddock et al., 2006), and the response coefficient of accruals on the negative versus positive cash flow models by Ball and Shivakumar (2005) modified by Ruddock et al. (2006). The result shows that ex ante conservatism (unconditional conservatism) or also called balance sheet conservatism has decreased. Because of fair value in the statement of financial position, the which previously used historical cost. Although the fair value was not completely eliminating conservatism, because of the lot of value of level 2 and 3. In contrast, the ex post conservatism (conditional conservatism) was also called income statement conservatism increased. This research shows that the arguments of IFRS are of fair value and financial statements, free from conservatism can be rejected. This study also shows that conservatism at a certain level is still needed because of the contracting efficiency.

Keywords : Convergence of IFRS, conservatism, conditional conservatism, unconditional conservatism
\end{abstract}

\section{Introduction}

The standards for preparing financial statements in Indonesia are guided by Standar Akuntansi Keuangan (SAK) issued by the Indonesian Accounting Association (IAI). SAK gives manager discretion to choose one alternative method and accounting estimation that can be used in accordance with company conditions. To anticipate unstable economic conditions and at the same time prevent the possibility of manipulation of financial statement presentation by management, companies must be careful in presenting their financial statements. This principle of prudence is in line with the concept of conservatism in the financial reporting process. Conservatism is one of the basic principles of historical accounting which plays the most role in explaining the concept of recognition, especially in uncertain circumstances (Tearney et al., 2001).

Conservatism is defined as the tendency of an accountant to require a higher level of verification to recognize earnings (good news in earnings) than to recognize losses (bad news in earnings) (Basu, 1997). In simple terms, conservatism in accounting can be interpreted through statements not anticipating profits, but anticipating all losses. An example of some accounting principles based on historical accounting conservatism is the lower recognition of the market price of inventory (market) on the inventory valuation and the recognition of reserves of loss of receivables in the receivable's valuation. 
Accounting conservatism is a very problematic concept in accounting. Very few accounting theorists like the idea of reducing assets and over-serving liabilities in a systematic manner, recognizing later income, and prioritizing expense recognition. However, conservatism has been, and probably still, as one of the most influential accounting principles in conventional accounting. The need for conservatism is always associated with the reliability of reporting past events, auditor accountability and behavior that are more emphasized.

But the goal of modern accounting standards (IFRS) is primarily oriented towards the future, directed at helping investors and other stakeholders in their decision making. Thus, conservatism is not used as an accounting principle in IFRS. Financial statements with Standar Akuntansi Keuangan (IFRS convergence) must be understandable, relevant, reliable and can be compared but without a conservatism bias.

Watts (2003) as a supporter of conservatism argues that conservatism is one of the most important characteristics in reducing agency costs and improving the quality of financial statement information so that in the end will $\mathrm{m}$ Enhancing corporate value and share price. Meanwhile Hendriksen (1982) states several arguments that support and reject conservatism. Arguments in favor of the concept of conservatism include conservatism from accountants important to compensate for excessive optimism managers and owners, valuing more profit earnings is more dangerous than profit less (the consequences of bankruptcy are more serious than profits), to reduce risk (risk of paying taxes, risk supervised by the government and securities analysts, the risk of high dividend payments to investors).

The contrary argument said that conservatism cannot be interpreted appropriately and is contrary to the purpose of all relevant information disclosure. Conservatism causes the information contained in financial statements to be biased because it is not in accordance with the matching concept principle where the recognition of revenue (revenue) must be in harmony and match with the recognition of the expense that causes the income.

Indonesian financial accounting standards convergence into International Financial Reporting Standards (IFRS) formulated by the International Accounting Standard Board (IASB) since 2008, and effective starting in the preparation of financial statements for 2011 for companies that have gone public. Financial accounting standards before IFRS convergence (henceforth the term conventional accounting anchor will be used) refers to historical cost-based has a relatively high level of conservatism compared to the level of conservatism in IFRS standards. This can be seen because SAK allows company accountants to choose one accounting method from several alternative methods that are allowed in the same situation. Whereas in IFRS, the freedom that is left to company management in the selection of accounting records methods is getting narrower and some recording methods used in SAK are not applied in IFRS standards, so the principle of conservatism that has been used by management has shifted. This shift is explicitly seen also with the use of terms, namely from conservatism to prudence (caution). The following examples show a comparison of certain Statements of Financial Accounting Standards (PSAK) that explain the differences in conservatism in conventional IFRS and IFRS (Aristiya, 2014) :1) in the stock assessment, the conventional SAK uses the LCM method (lower cost or market), while IFRS convergence SAK uses the LCNRV method ( lower of cost or net realizable value), with the LCOM rule, replacement cost is not higher than NRV and not lower from NRV minus markup, 2) in IAS 38 (Capitalization of Development Cost ) PSAK 19 concerning intangible assets. Intangible assets originating from development activities are recognized as assets if they meet certain requirements. Prior to the enactment of this standard, loading directly into the main reference in the accounting treatment of the cost of development, 3) the use of revaluation model in IAS 16 (Property, Plant, and Equipment) or IAS 16 (of fixed assets), and the recognition of a deferred tax asset if there may be a future taxable profit in IAS 12. This standard represents less conservative accounting regulations.

Empirically some previous studies have developed several models that can be used as proxies for accounting conservatism. Among the Basu (1997) models that use the market reaction approach, Givoly and Hayn (2000) use market to book ratios and nonoperating accruals and Paek et al (2007) by using 
negative earnings response coefficient and regression between operating cash flow and company accruals (Wijaya, 2012).

Conservatism is not a basic concept in the financial reporting process after the adoption of IFRS and has been replaced by prudence, but conservatism still needs to be considered. In essence, prudence is a precautionary concept in which there are still elements of conservatism. Prudence, especially related to the recognition of income, revenue that can be recognized even though it still in potential, insofar as it meets the provisions of revenue recognition in IFRS. After IFRS convergence, several studies have stated that conservatism has been lost or decreased (Ginting, 2014; Aristiya and Pratiwi, 2013; Piot et al., 2010). Conversely, there are several studies that state that conservatism actually increases after the IFRS convergence (Bertin and Moya, 2012; Zhang, 2012; Pham, 2009). The existence of differences in the results of these studies indicates that the presence of IFRS convergence does not necessarily reduce the level of conservatism of financial statement accounting. In addition, financial statements are prepared by accountants who already have a conservative character in uncertain conditions when dealing with recognition of income and expenses, so that even though IFRS is not found in the SAK, the term conservative is not found, but the emergence of the term prudence is felt to have no impact the reasoning used to choose the right accounting policy in the preparation of external financial reports.

Based on the literature, conservatism is divided into two, namely unconditional conservatism and conditional conservatism. Ex ante conservatism (unconditional conservatism) is a conservatism based on accounting, related to the balance sheet, and does not depend on the presence of good or bad news, or in other words independent of the presence of good or bad news in the company's business environment. Basu (1997) as the originator of ex post conservatism (conditional conservatism) where conditional conservatism is based on market conditions, related to earnings and depends on news (news dependent). Conservatism is a reaction or response to companies that do different verification as to information contained in a business environment that can affect company earnings, related to information on economic gains and losses. Accounting is conservative if the recognition of news that indicates economic losses is timelier than recognition of economic gains. In this study, we examined two types of conservatism after IFRS convergence. The problem that will be discussed in this study is whether there is a decrease in the level of accounting conservatism in accounting policies after the adoption of IFRS convergence of Standar Akuntansi Keuangan (SAK).

The application of IFRS in Indonesia caused a shift in the concept of conservatism. Because IFRS is more focused on the presentation of relevant financial statements that cause a higher dependence on estimates and various judgments. In addition, IFRS in principle based more use professional judgment in valuation. The professional judgment makes the company more optimistic because it can recognize changes in the value of an account in accordance with fair value.

The concept of conservatism is increasingly shifting when the IASB introduces a new principle of prudence. Where prudence is a precautionary principle that allows managers to recognize revenue even though it is still in the form of potential as long as it meets the provisions of revenue recognition in IFRS. But conservatism still needs to be considered because basically the two principles are not much different because the two principles contain elements of management prudence in making financial statements. After IFRS convergence, several studies have stated that this principle has been lost or decreased (Andre, 2011; Aristiya, 2013; Gafa, 2015; and Thijssen, 2015). Conversely there are several studies which state that accounting conservatism actually increases after IFRS convergence (Pham, 2009; Zhang, 2011; and Moya, 2012). In addition, several studies suggest that IFRS convergence has no effect on accounting conservatism (Jiang, 2012; and Yustina, 2013) and Piot's (2010) study which states conditional conservatism decreases after IFRS convergence while unconditional conservatism has increased. Thus a hypothesis can be stated: The level of conservatism (either conditional or unconditional conservatism conservatism) in accounting policy has decreased after the implementation of IFRS GAAP convergence. 


\section{Methods}

This study tested the hypothesis regarding the level of conservatism of financial statement accounting after the IFRS convergence. The population was manufacturing companies listed in Indonesia Stock Exchange (BEI) in 2008-2015 (involving also the period prior to the convergence of IFRS). The sample in this study uses purposive sampling, which is a method of selecting samples that have a specific goal or target.

Manufacturing company listed on the IDX

Manufacturing companies that do not publish financial statements in full

Financial statements that do not use the rupiah exchange rate

Companies whose stock prices are incomplete

Total Samples
143

Based on the above criteria, from a population of 143 companies, the total sample of this study was 75 manufacturing companies listed on the Indonesia Stock Exchange (IDX). The variable is accounting conservatism. This study compares the level of accounting conservatism, both the unconditional conservatism and conditional conservatism, from year to year before and after IFRS convergence. The measurement of accounting conservatism in this study uses the development of the Basu (1997) model by Ismail and Elbolok (2011), namely:

$$
\frac{E P S_{i t}}{p_{i t}}=\delta_{0}+\delta_{1} D R_{i t}+\delta_{2} R E T_{i t}+\delta_{3} D R_{i t}^{*} R E T_{i t}+\delta_{4} C F O_{i t} / N I_{i t}+\delta_{5} M T B_{i t}+\varepsilon_{i t}
$$

EPS: Earnings per Share of company i year $t$, P: opening stock market price company i year $t$, RET: Stock market return year $t$, DR: Dummy variable, equal to 1 , if negative return, equal to 0 if positive return. If bad news is recognized in a timelier manner than good news, $\delta_{3}$ will be greater than zero $\left(\delta_{3}>0\right)$. The greater the $\delta_{3}$, the greater the conditional conservatism. The greater $\delta_{5}$ (regress of market value against the book value of the company), the greater the unconditional conservatism.

To see the consistency of the results, a study will also be conducted to look at the level of conservatism using other measurement methods (Paek et al, 2007) as a sensitivity analysis:

1. Negative earnings response coefficient which is formulated with the following equation.

$$
\Delta O I_{t}=d_{0 t}+d_{1 t} D O I_{t-1}+d_{2 t} \Delta O I_{t-1}+\left(-d_{a t}\right) D O I_{t-1} * \Delta O I_{t-1}+e_{t}
$$

$\Delta \mathrm{OI} t=$ Change in operating income in year $\mathrm{t}$, IOI $\mathrm{t}-1=$ Change in operating income in year $\mathrm{t}-1, \mathrm{DOI} \mathrm{t}-1=$ Dummy variable with (1) if the change in operating profit is negative, (0) for positive operating profit changes, DOI $t_{-1}^{*} \Delta \mathrm{OI} t-1=$ Interaction between changes in operating income in year $\mathrm{t}-1$ and dummy variables, $-\mathrm{d}_{3 \mathrm{t}}=$ Conservatism proxy, if the negative coefficient value indicates the company applies conservative accounting. Because $\Delta \mathrm{OI}_{\mathrm{t}}$ is inversely proportional to $\Delta \mathrm{OI}_{\mathrm{t}-1 .}$. Negative coefficients indicate that in the previous year the company applied conservative accounting, so that it will affect changes in earnings in the current year.

2. The response coefficient of accruals on negative versus positive cash flow is formulated with the following equation

$$
A C C_{\mathrm{t}}=e_{0 \mathrm{t}}+e_{1 \mathrm{t}} D C F O_{\mathrm{t}}+e_{2 \mathrm{t}} C \mathrm{O}_{\mathrm{t}}+e_{\mathrm{at}} \mathrm{DCFO}_{\mathrm{t}}{ }^{*} \mathrm{CFO}_{\mathrm{t}}+e_{\mathrm{t}}
$$

ACC $\mathrm{t}=$ Operating income is reduced by the company's operating cash flow divided by the company's total assets, $\mathrm{CFO}_{\mathrm{t}}=$ Operating cash flow divided by the total assets of the company, $\mathrm{DCFO}_{\mathrm{t}}=\mathrm{Dummy}$ variable for operating cash flows where (1) if the operating cash flow is negative and (0) if the operating 
flow is positive, $\mathrm{DCFO}{ }_{\mathrm{t}}{ }^{\mathrm{C}} \mathrm{CFO}=$ Interaction between dummy variables and operating cash flows, $e_{3 \mathrm{t}}=$ Conservatism proxy, if the positive coefficient shows the company applies conservative accounting, because the positive coefficient shows the company's cash flow is negative, the negative cash flow indicates that the company is conservative .

Analysis by describing value of conservatism obtained by dividing it into 3 groups of data, namely, all sample, before the convergence of IFRS, and after the convergence of IFRS. Hypothesis testing is done by the development model of Basu (1997) and an additional model is a model Negative earnings response coefficient and the model Response coefficient of accruals on positive versus negative cash flow by Paek., Et al (2007).

\section{Results and Discussion}

This study uses panel data, namely a combination of cross-sectional data (cross section) with time series data (time series). Thus, there are several methods that can be used in estimating regression models with panel data, namely pooling least square (common effect), fixed effect approach (fixed effect), and random effect approach. In determining the best model, there are two techniques that can be used, namely Chow test and Hausman test. Chow test to choose between common effect and fixed effect, and Hausman test to choose fixed effect and random effect.

There are three models that are used to obtain empirical evidence of the application of conservatism in accounting policies for external financial reporting. In essence the three models see a response to bad news, namely the response coefficient to negative returns, the response coefficient to negative operating profit and the response coefficient to negative cash flow. The response was seen before the application of international accounting standards (IFRS convergence) and after the application of international accounting standards (IFRS convergence), with the hypothesis that the response coefficient after IFRS was lower than before IFRS (there was a decrease in conservatism after IFRS convergence). Officially, convergence began in 2011, so that after IFRS was in 2012-2015. Whereas before IFRS was the period from 2008-2011. From the table above it can be seen, used 5 groups of data using fixed effects and 4 groups of data with random effects.

Hypothesis testing is done by using multiple regression analysis. This study uses the Basu (1997) model developed by Ismail and Elbolok (2011). Data processing is used based on samples from 2008-2015, where prior to IFRS for 2008-2011 and after IFRS for 2012-2015. Overall, the observations are unbalanced, there are 572 years of company data, for before IFRS with 261 years-company data and after IFRS with 284 years-company data.

Data analysis was carried out with three stages of testing, namely all samples, before IFRS and after IFRS. From all sample testing, with $\mathrm{F}$ value 5.367 greater than $\mathrm{F}$ table and significant at $\alpha 1 \%$ and with a corresponding determination coefficient of $37.06 \%$. In other words, this shows the model with all samples has been fixed. Whereas for the second model, before IFRS, with F value 28.94491 and significant at $\alpha 1 \%$, so also the third model, after IFRS with $\mathrm{F}$ value 1.701969 is significant at $\alpha 1 \%$. The determination coefficient before IFRS was $34.95 \%$ and decreased for IFRS after being $15.86 \%$. So that all three models have been fixed. 
Table 1 Regression Model

\begin{tabular}{lll}
\hline \multicolumn{1}{c}{ Panel Testing Model } & N & Estimated Regression Model \\
\hline $\begin{array}{l}\text { Model 1. } \\
\text { Earnings / stock return relations meansure (Basu, } \\
\text { 1997) }\end{array}$ & & \\
\hline All sample, unbalanced observations & 572 & Fixed effect-Cross Sectionweight \\
\hline Before IFRS, unbalanced observations & 261 & Randomeffect-Cross Sectionweight \\
\hline After IFRS, unbalanced observations & 284 & Fixed effect \\
\hline
\end{tabular}

Model 2.

Negative response coefficient of change in operating income (Paek. Et al, 2007)

\begin{tabular}{lll}
\hline All samples, balanced observations & 450 & Fixed effect \\
\hline Before IFRS, balanced observations & 300 & Randomeffect-Cross Sectionweight \\
\hline Table Cont... & & \\
\hline After IFRS, balanced observations & 150 & Randomeffect-Cross Section weight \\
\hline
\end{tabular}

Model 3.

Response coefficient of accruals on negative versus positive cash flow

\begin{tabular}{lll}
\hline All samples, balanced observations & 600 & Fixed effect \\
\hline Before IFRS, balanced observations & 300 & Randomeffect-Cross Sectionweight \\
\hline After IFRS, balanced observations & 300 & Fixed effect \\
\hline
\end{tabular}

Source: Self-processed, 2019

Conservatism in accounting policy can be seen from the negative return coefficient on EPS for conditional conservatism and the firm value coefficient (MTB) for EPS for unconditional conservatism. From the results of the all sample test can be seen the negative return coefficient value of 2.068850 and significant at $\alpha 5 \%$ while the MTB coefficient is -0.274416 and significant at $\alpha 1 \%$. This shows that there is conservatism in the application of accounting policies, both conditional and unconditional. However, based on tests that distinguish the period before and after conservatism, conditional conservatism (negative return / DRet) is not significant in the period before IFRS but is significant at $\alpha 10 \%$ after IFRS with a coefficient of 4.99 6200. For unconditional conservatism both before IFRS and after convergence IFRS convergence is significant at $\alpha 1 \%$, but the coefficient decreases from -0.531537 to $-0,473186$. This shows a decline in unconditional conservatism after the adoption of IFRS convergence accounting standards. Conditional conservatism is inversely proportional to unconditional conservatism (Lawrence et al., 2013). The higher conditional conservatism, the smaller the unconditional conservatism.

From the comparison of the coefficient of determination of the model before and after IFRS can also be used to see whether conservatism (conditional and unconditional) has decreased after IFRS convergence. The coefficient of determination has decreased from the period before IFRS which amounted to $34.95 \%$ to $15.86 \%$, this indicates that conservatism has decreased after IFRS convergence. Thus, it can be concluded that conservatism remains in the application of accounting policies, but generally decreases after IFRS convergence. If compared to the conservatism, conditional conservatism has increased, while unconditional conservatism has decreased after IFRS convergence. 
Table2MultipleRegression Test Results with Basu DevelopmentModel, 1997(Model1)

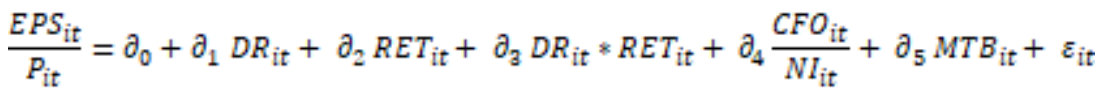

Hypothesis: The level of conservatism (both conditional conservatism and unconditional conservatism) in accounting policy has decreased after the application of IFRS convergence.

\begin{tabular}{|c|c|c|c|c|}
\hline & $\begin{array}{c}\text { Prediction } \\
\text { Relationship }\end{array}$ & $\begin{array}{c}\text { All samples } \\
\begin{array}{c}\text { Coefficient } \\
\text { (t-Statistic) }\end{array}\end{array}$ & $\begin{array}{c}\text { Before IFRS } \\
\text { Coefficient } \\
\text { (t-Statistic) }\end{array}$ & $\begin{array}{l}\text { After IFRS } \\
\text { Coefficient } \\
\text { (t-Statistic) }\end{array}$ \\
\hline Intercept & & $\begin{array}{c}\mathbf{0 . 5 5 2 2 6 4} \\
(26,48017)^{* * *}\end{array}$ & $\begin{array}{c}-1,924182 \\
(-14,60487)^{* * *}\end{array}$ & $\begin{array}{c}\mathbf{0 . 6 1 0 1 0 4} \\
(5,861902)^{* * *}\end{array}$ \\
\hline DRet & - & $\begin{array}{c}-\mathbf{0 . 1 7 2 3 1 7} \\
(-0,505133)\end{array}$ & $\begin{array}{c}-0.775268 \\
(-0,704000)\end{array}$ & $\begin{array}{c}-2,700204 \\
(-3,490355)^{* * *}\end{array}$ \\
\hline$D *$ Ret & $+(H)$ & $\begin{array}{c}\mathbf{2 , 0 6 8 8 5 0} \\
(2,255323) * *\end{array}$ & $\begin{array}{c}\mathbf{5 . 3 8 1 4 5 8} \\
(1.441084)\end{array}$ & $\begin{array}{c}4,996200 \\
(1,723034) *\end{array}$ \\
\hline CFO & - & $\begin{array}{c}-\mathbf{0}, 000092 \\
(-0,356928)\end{array}$ & $\begin{array}{c}-0.004401 \\
(-7.602477)^{* * *}\end{array}$ & $\begin{array}{c}-\mathbf{0 , 0 0 0 1 3 1} \\
(-0.071400)\end{array}$ \\
\hline МТВ & $-(H)$ & $\begin{array}{c}-\mathbf{0 . 2 7 4 4 1 6} \\
(-9,519451)^{* * *}\end{array}$ & $\begin{array}{c}-0.531537 \\
(-10.04062)^{* * *}\end{array}$ & $\begin{array}{c}-\mathbf{0 , 4 7 3 1 8 6} \\
(-3,617835)^{* * *}\end{array}$ \\
\hline $\begin{array}{c}\text { Adjustable } \\
\text { R2 }\end{array}$ & & $37.06 \%$ & $34.95 \%$ & $15.86 \%$ \\
\hline F-stat & & $\begin{array}{c}5,367940 \\
* * * \\
\text { Fixed Effect }\end{array}$ & $\begin{array}{c}28,94491 \\
* * * \\
\text { Random Effect }\end{array}$ & $\begin{array}{c}1.701969 \\
* * * \\
\text { Fixed Effect }\end{array}$ \\
\hline $\mathbf{N}$ & & 572 & 261 & 284 \\
\hline
\end{tabular}

Note: EPS: Earnings per Share of company to year $\mathrm{i}, \mathrm{P}$ : opening stock market price of company $\mathrm{i}$ year $\mathrm{t}$, RET: Stock market return year $\mathrm{t}$, DR: dummy variable, equal to 1, if negative return, equal to 0 if return positive, the company's CFO/NI for the year i: cash flow operation is divided into income, MTB: market to book value. If bad news is recognized in a timelier manner than good news, $\delta 3$ will be greater than zero $(\delta 3>0)$. The greater the $\delta 3$, the greater the conditional conservatism. The greater $\delta 5$ (regress of market value against the book value of the company), the greater the unconditional conservatism. *** Significant at the level of $1 \%$ one tailed, ** Significant at the level of 5\% one tailed, * Significant at the level of $10 \%$ one tailed

Source: Self-processed, 2019

Additional test results, to see the consistency of the results, a negative earnings response coefficient was tested and the response coefficient of accruals model on negative versus positive cash flow by Paek, et al (2007), but this model did not distinguish between conditional and unconditional conservatism .

Based on Table 3 above, it can be seen that the model has been fixed, where the model is produced with F count of 1.676 for the all sample group, 30.7776 for before IFRS and 13.455 for after IFRS and all significant at $\alpha 1 \%$. The determination coefficient shows $10.39 \%$ in all samples, $37.48 \%$ for before IFRS and $11.11 \%$ for after IFRS.

Accounting conservatism can be seen from the previous year's negative earnings response coefficient or value $d_{3} d_{3 t}$. The test results showed the coefficient of the negative earnings response in the previous year for all samples -0.865629 and significant at $\alpha 1 \%$. Before IFRS, there was conservatism with a coefficient value of -2.147023 significant at $\alpha 1 \%$, while after IFRS conservatism the coefficient value decreased to -0.920034 and also significant at $\alpha 1 \%$. So can be concluded that the hypothesis cannot be 
denied that conservatism has decreased after IFRS convergence. This is in line with Andre's research, 2011; Aristiya, 2013; Gafa, 2015; and Thijssen, 2015.

Table 3 Multiple Regression Test Results Negative Earnings Response Coefficient Model (Model 2)

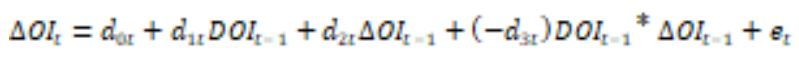

Hypothesis: The level of conservatism (both conditional conservatism and unconditional conservatism) in accounting policy has decreased after the application of SAK convergence IFRSs.

\begin{tabular}{|c|c|c|c|c|}
\hline & $\begin{array}{c}\text { Prediction } \\
\text { Relationship }\end{array}$ & $\begin{array}{c}\text { All samples } \\
\text { Coefficient } \\
\text { (t-Statistic) }\end{array}$ & $\begin{array}{c}\text { Before IFRS } \\
\text { Coefficient } \\
\text { (t-Statistic) }\end{array}$ & $\begin{array}{l}\text { After IFRS } \\
\text { Coefficient } \\
\text { (t-Statistic) }\end{array}$ \\
\hline Intercept & & $\begin{array}{c}-0,0000 \\
(-0,159651)\end{array}$ & $\begin{array}{c}\mathbf{0 . 0 0 0 0} \\
(0.156435)\end{array}$ & $\begin{array}{c}\mathbf{0 . 0 0 0 0} \\
(-1,188848)\end{array}$ \\
\hline DOI & + & $\begin{array}{c}\mathbf{0 . 0 0 0 0} \\
(0.648516)\end{array}$ & $\begin{array}{c}\mathbf{0 . 0 0 0 0} \\
(0,052812)\end{array}$ & $\begin{array}{c}\mathbf{0 . 0 0 0 0} \\
(0,238546)\end{array}$ \\
\hline IOI $t-1$ & + & $\begin{array}{c}0.2929 \\
(2,918191)^{* * *}\end{array}$ & $\begin{array}{c}0.710868 \\
(11,37993)^{* * *}\end{array}$ & $\begin{array}{c}\mathbf{0 . 3 0 7 1 3 0} \\
(4,728531)^{* * *}\end{array}$ \\
\hline Adjustable R2 & & $10.39 \%$ & $37.48 \%$ & $11.11 \%$ \\
\hline \multirow[t]{2}{*}{ F-stat } & & $\begin{array}{c}1,676160 \\
* * *\end{array}$ & $\begin{array}{c}30,77613 \\
* * *\end{array}$ & $\underset{* * *}{13.45577}$ \\
\hline & & Fixed Effect & Random Effect & Random Effect \\
\hline $\mathbf{N}$ & & 450 & 150 & 300 \\
\hline
\end{tabular}

Note: $\Delta \mathrm{OI} t=$ Change in operating income in year $\mathrm{t}, \Delta \mathrm{OI} \mathrm{t}-1=$ Change in operating income in year $\mathrm{t}-1$, DOI $\mathrm{t}-1=\mathrm{Variable}$ dummy with (1) if the change in operating profit is negative, $(0)$ for change positive operating profit, $\mathrm{DOI} t-1^{*} \Delta \mathrm{OI} t-1=$ Interaction between operating income changes in year $t-1$ and dummy variables, $-d_{3 t}=$ Proxy conservatism, if the negative coefficient value indicates the company applies conservative accounting. Because ItOIt is inversely proportional to $\Delta$ OIt-1. Negative coefficients indicate that in the previous year the company applied conservative accounting, so that it will affect changes in earnings in the current year.

*** Significant at the level of $1 \%$ one tailed, ** Significant at the level of $5 \%$ one tailed, ** Significant at the level of $10 \%$ one tai led

Ball and Shivakumar (2005) and Ruddock et al. (2006) developed a negative relationship between accruals and cash flow as in Dechow et al. (1998) to involve asymmetry recognition of bad news and good news. If economic losses are recognized on a more timely basis (which is usually the result of accruals) rather than economic benefits (which are usually the result of cash imposition), the negative relationship of accruals-cash flows is reduced by the existence of negative cash flow $e 3$ tis predicted to be positive).

Tests carried out on 600 years of observation of manufacturing companies from 2008-2015 using the R model of the Coefficient of Accruals on Negative versus Positive Cash Flow. The test results show all fix models, with F count 14.43857 for all samples, 114.6235 for before IFRS and 7.769475 for after IFRS, all of which are above $\mathrm{F}$ table and significant at $\alpha 1 \%$. Coefficient of determination (adjusted R2) $63.33 \%, 53.27 \%$ and $63.54 \%$ respectively. If seen from the dummy interaction coefficient and operational cash flow ( ${ }^{*} \mathrm{CFO}$ ), it can be seen all the models are significant at $\alpha 1 \%$, but the direction of the coefficient is negative, while the model estimates are positive. Thus, accruals to positive and negative operating cash flows do not indicate conservatism, and it can be concluded the hypothesis is rejected. 
Table4Multiple Regression Test Results Model R concept of the Coefficient of Accruals on Negative versus Positive CashFlow (Model3)

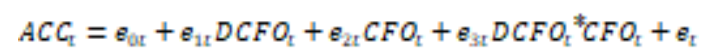

Hypothesis: The level of conservatism (both conditional conservatism and unconditional conservatism) in accounting policy has decreased after the application of IFRS convergence IFRSs.

\begin{tabular}{|c|c|c|c|c|}
\hline & $\begin{array}{c}\text { Prediction } \\
\text { Relationship }\end{array}$ & $\begin{array}{c}\text { All samples } \\
\text { Coefficient } \\
\text { (t-Statistic) }\end{array}$ & $\begin{array}{l}\text { Before IFRS } \\
\text { Coefficient } \\
\text { (t-Statistic) }\end{array}$ & $\begin{array}{c}\text { After IFRS } \\
\text { Coefficient } \\
\text { (t-Statistic) }\end{array}$ \\
\hline Intercept & & $\begin{array}{c}\mathbf{0 . 0 7 7 7 8 9} \\
(15,77194)^{* * *}\end{array}$ & $\begin{array}{c}\mathbf{0 . 0 6 8 3 4 6} \\
(7.555308)^{* * *}\end{array}$ & $\begin{array}{c}\mathbf{0 . 0 6 8 4 0 5} \\
(9.753277)^{* * *}\end{array}$ \\
\hline DCFO & + & $\begin{array}{c}\mathbf{0 . 0 1 4 7 7 1} \\
(1,508793)\end{array}$ & $\begin{array}{c}\mathbf{0 . 0 3 6 2 7 3} \\
(3.085612)\end{array}$ & $\begin{array}{c}\mathbf{0 . 0 1 3 0 8 4} \\
(0.866282)\end{array}$ \\
\hline CFO & + & $\begin{array}{c}-\mathbf{0 , 6 1 6 4 9 0} \\
(-17,59314)^{* * *}\end{array}$ & $\begin{array}{c}-0.497137 \\
(-11.01397)^{* * *}\end{array}$ & $\begin{array}{c}-\mathbf{0 . 5 9 8 0 1 6} \\
(-12.22294)^{* * *}\end{array}$ \\
\hline $\mathrm{D} * \mathrm{CFO}$ & $+(H)$ & $\begin{array}{c}-\mathbf{0 . 2 3 1 6 4 9} \\
(-2,477792)^{* *}\end{array}$ & $\begin{array}{c}\mathbf{0 . 1 9 8 5 3 3} \\
(-1.896034)^{* *}\end{array}$ & $\begin{array}{c}\mathbf{0 . 4 9 4 4 2 8} \\
(-3.116670)^{* * *}\end{array}$ \\
\hline Adjustable R2 & & $63.33 \%$ & $53.27 \%$ & $63.54 \%$ \\
\hline F-stat & & $\begin{array}{l}14,43857^{* * *} \\
\text { (Fixed effect) }\end{array}$ & $\begin{array}{c}114,6235^{* * *} \\
\text { (Random effect) }\end{array}$ & $\begin{array}{c}7,769475 \\
\text { ( fixed effect) }\end{array}$ \\
\hline $\mathbf{N}$ & & 600 & 300 & 300 \\
\hline
\end{tabular}

Note: $\mathrm{ACC}_{\mathrm{t}}=$ Operating income is reduced by the company's operating cash flow divided by the company's total assets, $\mathrm{CFO}=$ Operating cash flow divided by total company assets, DCFO $\mathrm{t}=$ dummy variable for operating cash flows where (1) if the operating cash flow is negative and ( 0$)$ if the operating current is positive, $\mathrm{DCFO}{ }_{t}{ }^{*} \mathrm{CFO}=$ Interaction between dummy variables and operating cash flows

$e_{3} \mathrm{t}=$ Proxy conservatism, if the positive coefficient shows the company applies conservative accounting. because the positive coefficient shows the company's cash flow is negative, negative cash flow indicates that the company is conservative

*** Significant at the level of $1 \%$ one tailed, ** Significant at the level of $5 \%$ one tailed, ** Significant at the level of $10 \%$ one tai led

Source: Self-processed, 2019

Accounting conservatism is a very problematic concept in accounting. There is still debate over the need for conservatism or not in financial reporting. But theoretically conservatism has emerged because of several reasons such as litigation, efficient contracting, taxation aspects and regulation (Watt, 2003). This makes conservatism still needed. Besides conservatism is also still associated with the reliability of reporting past events, auditor accountability and behavior are more emphasized.

Adoption of IFRS as a single set of principle-based accounting standards, and abandoning local accounting standards is aimed at increasing financial reporting quality through a set of " high quality standards," especially through conditional financial reporting conservatism. Some literature divides conservatism into two, namely ex ante conservatism (also called balance sheet conservatism and ex post conservatism (conditional conservatism), also called the income statement conservatism (Pope and Walker, 1999; Ball et al., 2000; Beaver and Ryan, 2005). Conservatism ex ante (unconditional conservatism) is conservatism based on accounting, related to the balance sheet, and does not depend on the presence of good or bad news, or in other words independent of the presence of good or bad news in the company's business environment. This type of conservatism is for example not recording goodwill or carrying out relatively fast loading on R \& D activities, marketing activities (advertising) or the use of accelerated allocation methods (depreciation of double declining balances), resulting in understated asset book value. This type of conservatism produces more persistent earnings (consistent in the long run) because conservatism is carried out in the accounting policies carried out, where the consistency of treatment is more consistent. 
Basu (1997) as the originator of ex post conservatism (conditional concervatism) where conditional conservatism is based on market conditions, related to earnings and depends on news (news dependent), meaning that this form of conservatism is a reaction or response from companies that do different verification as the absorption of information contained in a business environment that can affect company earnings related to information that can result in economic gains and losses. Accounting is conservative if the recognition of news indicates losses the economy is timelier than recognition of economic gains. Conditional conservatism is more aggressive in recognizing bad news than recognition of good news and is considered a key qualitative characteristic of financial reporting (Watts, 2003; Francis et al., 2004; Francis et al., 2006; Ball et al., 2008; Dechow et al., 2010; Kathori et al., 2010 in Andre et al., 2013). This form of news-dependent prudence is to ensure that potential economic losses are reported in earnings in a timely manner, and the recognition of potential economic benefits is delayed. Conditional conservatism this is different from unconditional conservatism, known as ex ante or news-independent prudence, which shows understating the book value of net assets relative to economic value, independently of any news (Pope and Walker, 2003; Beaver and Ryan 2005).

The impact of IFRS adoption on conservative conditionals is an unclear priority. There is often an argument that IFRS is "less prudent" than national GAAP (national SAK) and notes that there are two arguments related to this. The first argument, the term prudence has been removed from the conceptual framework (IASB, 2010), and the second argument, IFRS allows a number of fair value options that will make it not prudent. Regarding prudence IFRS, conflict with quality is neutrality, but in reality, the council explained in 2008 that: "[T] he exercises of prudence does not allow for deliberate understatement of assets or income or overstatement of liabilities or expenses. [...] Introducing bias in understatement of assets (or overstatement of liabilities) in one period often leads to overstating financial performance later periods - a result that cannot be described as prudent "(IASB, 2008). The form of prudence referred to by IFRS regarding erasers of conceptual frameworks (or financial reporting) can be clearly related to unconditional conservatism, and not conditional conservatism. In addition, clearly, the board describes a negative relationship between unconditional and conditional conservatism (Pope and Walker, 2003; Beaver and Ryan, 2005; Lawrence et al., 2013). Regarding the second argument, fair value in asset reporting does not have a significant impact on many industries than the financial sector, and if the company decides to use fair value options, both unrealized gains (good news) and unrealized losses (bad news) are not recognized in profit (or other comprehensive income). Fair value cannot be considered less conservative conditional than the cost of amortization (Andre, 2013)

The results of this study indicate that conservatism still has financial reporting in manufacturing companies in Indonesia. From the results of testing before IFRS, conditional conservatism has no effect on earnings or shows conditional accounting conservatism does not play a role before IFRS, but after IFRS, conditional accounting conservatism is significant and significant. This shows that there is an increase in the application of conditional conservatism after IFRS. This study contradicts the results of the research by Andre et al., 2013 which stated that there was a decrease in conditional conservatism after IFRS. But this research is in line with Pham's research, 2009; Zhang, 2011; and Moya, 2012, which states that conservatism has increased after IFRS convergence, although these studies do not distinguish between conservatism.

Thus, this (the finding of increasing conditional conservatism in financial reporting of manufacturing companies in Indonesia) contradicts the argument of Andre (2013) above which states that fair value cannot be considered less conservative conditional than the cost of amortization. But from the results of Ryan's research (2016) found that the measurement of conservative fair value is conditional, because it uses fair value level 2 and level 3, where level 2 and level 3 are influenced by discretion and are subjective. Thus, this proves that the use of fair value in financial reporting of manufacturing companies in Indonesia is also thought to be conservative conditionally, because of assets still the largest asset 
component in a manufacturing company cannot be applied to a level 1 fair value, because there is no quoted market.

This study is inversely proportional to unconditional conservatism, the results of this study indicate a decline in unconditional conservatism. This is in line with Pope and Walker, 2003; Beaver and Ryan, 2005, which states that there is a negative relationship between unconditional and conditional conservatism. Besides this, this is in line with Andre's research, 2011; Aristiya, 2013; Gafa, 2015; and Thijssen, 2015, who found that conservatism decreased after IFRS convergence, but which experienced a decline in unconditional conservatism. And even in aggregate, financial reporting conservatism after IFRS has decreased, this is seen from adjusted R2, which decreased from $34.95 \%$ before IFRS to $15.86 \%$ after IFRS convergence.

The findings of this study are supported by conservatism testing with the Negative earnings response coefficient model, which shows a decrease in conservatism from before IFRS -2.147023 to -0.920034 after IFRS. In addition, there was a decrease in adjusted $\mathrm{R}{ }^{2}$ from $37.48 \%$ to $11.11 \%$. As for the Response coefficient of accruals model on negative versus positive cash flow, hypothesis is rejected, where there is no decrease in conservatism after IFRS which is seen from the absence of the influence of positive and negative operational cash flows on accruals. This condition is different from the existence of conservatism by looking at the effect of negative operating profits on changes in operating profit, which is more conservative in conditional conservatism. For conservatives who see the effect of operating cash flows on accruals, which have no effect, it shows that the company is not too conservative about the company's accounting policies that have consequences on operating cash flows.

It can be concluded that conservatism ex ante (unconditional conservatism) or also known as the balance sheet conservatism decreased. This is due to the use of fair value in several measurements in the statement of financial position, which previously used many historical costs. Although the use of fair value does not completely eliminate conservatism, for example: 1) measurement of impairment of receivables using the concept of net realizable value using the concept of discounting receivables to be collected, 2) valuation of lower of cost or realizable value on stocks, namely comparing the cost of the stock with fair value after estimating the cost of completion and sale, 3) valuation of the cost model or revaluation model on the value of fixed assets, and many others, but the concept of fair value measurement is conservative because it uses fair value measurements level 2 and level 3. Thus, conditional conservatism has decreased, although it has not completely eliminated conservatism.

But on the contrary, ex post conservatism (conditional conservatism) is also called income statement conservatism has increased. The increase in conditional conservatism is due to a high level of verification to recognize the profit rather than loss verification, which has an impact on the reported earnings figures.

This research can prove that the argument that states that IFRS uses fair value, financial statements free from conservatism can be rejected. This research proves that conservatism at a certain level is still needed because to keep the contract in an efficient state.

\section{References}

Andre, Paul \& Andrei Filip. (2011). Accounting Conservatism in Europe and the Impact of Mandatory IFRS Adoption: A Look at Legal Incentives, Financial Systems and Accounting Traditions. ESSEC Business School.

Aristiya, Maria Maya dan Pratiwi Budiharta. (2014). Analisis Perbedaan Tingkat Konservatisme Akuntansi Laporan Keuangan Sebelum dan Sesudah Konvergensi IFRS. Jurnal Fakultas Ekonomi Universitas Atmajaya Yogyakarta.

Balachandran, S., \& Mohanram, P. (2011). Conservatism and the value relevance of accounting information. Review of Accounting Studies, 16, 272-301. 
Ball, R. and Shivakumar, L. (2005), Earnings quality in UK private firms: Comparative loss recognition timeliness. Journal of Accounting and Economics, Vol. 39, No.1, pp.83-128.

Ball, R., Kothari, S. P., and Nikolaev, V. (2010), Econometrics of the Base Asymmetric Timeliness Coefficient and Accounting Conservatism, working paper, Chicago Booth Research Paper No. 09-16, available at SSRN: http://ssrn.com/abstract=999710 (accessed 10 December, 2010).

Basu, S. (1997). The Conservatism Principle and The Asymmetric Timeliness of Earnings. Journal of Accounting and Economics. Vol.24, No. 1: 3-37.

Beaver, W. H., \& S. G. Ryan. (2005). Conditional and Unconditional Conservatism: Concepts and Modeling. Review of Accounting Studies 10, 269-309.

Bertin, M. Jara and Jose Thomas Arias Moya. (2013). The Effect of Mandatory IFRS Adoption on Accounting Conservatism of Reported Earnings: Evidence from Chilean Firms. Academia. Vol. 26 No. 1, p. 139-169.

Chen, Qiwei \& Ying Jiang. (2012). The Impact of Mandatory IFRS Adoption on Accrual Anomaly and Earning Conservatism. Brunel University London.

Dewi, A.A.A. Ratna. (2004). Pengaruh Konservatisme Laporan Keuangan Terhadap Earnings Response Coefficient. Jurnal Riset Akuntansi Indonesia. Vol. 7 No. 2, p. 207-223.

Fala, Dwiyana A.S., (2007). Pengaruh Konservatisma Akuntansi Terhadap Penilaian Ekuitas Perusahaan Dimoderasi Oleh Good Corporate Governance. Simposium Nasional Akuntansi X. Makasar.

Gafa, Alfian Noviandika, Sri S., dan Halim D. Perdana. (2015). The Comparison of Accounting Conservatism Level Between Before and After the Convergence of IFRS in Indonesia with Earnings and Accrual Method. Proceeding: International Conference on Accounting, Business E Economics, 324333.

Ginting, Edisa Putra. (2014). Pengaruh Pengadopsian IFRS Terhadap Penerapan Prinsip Konservatif Laba pada Perusahaan Manufaktur yang Listing di Bursa Efek Indonesia. Skripsi Universitas Bengkulu.

Givoly, D. And C. Hayn. (2000). The Changing Time-series Properties of Earning, Cash Flows and Accruals: Has Financial Reporting Become More Conservatism? Journal of Accounting and Economics. Vol. 29, p. 287-320.

Handojo, Irwanto. (2012). Sekelumit Konservatisme Akuntansi. STIE Trisakti. Jakarta.

Hellman, Niclas. (2007). Accounting Conservatism Under IFRS. Accounting in Europe, 5 (2): 71-100.

Hikmah, Luthfiany. (2013). Analisis Perbedaan Prinsip Konservatisme Akuntansi dalam Penerapan IFRS. Accounting Analysis Journal. Vol. 2 No. 3.

Idris. (2010). Aplikasi Model Analisis Data Kuantitatif dengan Program SPSS: Edisi Revisi III. Padang: Fakultas Ekonomi UNP.

Ismail, Tariq H dan Rash M Elbolok. (2011). Do Conditional and Unconditional Conservatism Impact Earnings Quality and Stock Prices in Egypt?. Research Journal of Finance and Accounting. Vol.2 No. 12.

Kuspratiwi, Indhira \& Ari K. W. (2014). Pengaruh Konvergensi IFRS dan Kepemilikan Saham Asing Terhadap Konservatisme Akuntansi. Economics \& Business Research Festival.

Martani, Dwi, Sylvia V., Ratna W., Aria F., Edward T. (2012). Akuntansi Keuangan Menengah Berbasis PSAK. Jakarta: Salempa Empat.

Paek, Wonsun, Lucy H. Chen, and Sami H. (2007). Accounting Conservatism, Earning Persistance and Pricing Multiples on Earning. Accounting Horizons.

Penman, S. H., \& X. J. Zhang. (2002). Accounting Conservatism, The Quality of Earnings, and Stock Return. The Accounting Review, 77 (2): 237.

Pham, Hang Minh. (2009). Accounting Conservatism in International Financial Reporting Standards and US Generally Accepted Accounting Principles. Inquiry. Vol. 10.

Piot, C., Dumontier, P., \& Janin, R. (2010). IFRS Consequences on Accounting Conservatism Within Europe. Working Paper. University of Grenoble and CERAG-CNRS. 
Pope, P. F., \& M. Walker. (1999). International Differences in the Timeliness, Conservatism, and Classification of Earnings. Journal of Accounting Research, 37, 53-87.

Ruddock, C., Taylor, S. J., Taylor, S. L., (2006). Nonaudit services and earnings conservatism: Is auditor independence impaired? Contemporary Accounting Research 23, 701-746

Scott, William R. (2009). Financial Accounting Theory, 5th Ed. Canada: Prentice-Hall.

Sidiyanti, Vita. (2016). Analisis Implementasi Prinsip Akuntansi Konservatisme Sebelum Dan Sesudah Konvergensi IFRS, Universitas Jember. Jember

Suwardjono. (2005). Teori Akuntansi: Perekayasaan Pelaporan Keuangan. Yogyakarta: BPFE.

Taiwah, V. K. \& Muhaheranwa Benjamin. (2015). Conservatism Analysis on Indian Generally Accepted Accounting Principles (GAAP) and International Financial Accounting Standards (IFRS). International Journal of Multidisciplinary Research and Development, 2 (5).

Tearney, Michael G., Harry I. Wolk dan James L. Dodd. (2001). Accounting Theory: A Conseptual and Institutional Approach. South-Western College Publishing. USA.

Wijaya, Anggita Langgeng. (2012). Pengukuran Konservatisme Akuntansi: Sebuah Literatur Review. ASSET: Jurnal Akuntansi dan Pendidikan. Vol. 1, No. 1.

Watts, R. L. (2003). Conservatism in Accounting Part I: Explanations and Implications. Accounting Horizons. Vol. 17, No. 3: 207-221.

Watts, R. L. (2003). Conservatism in Accounting Part II: Evidence and Research Opportunities. Accounting Horizons. Vol. 17, No. 4: 287-301.

Yustina, R. (2013). Pengaruh Konvergensi IFRS dan Mekanisme Good Corporate Governance Terhadap Tingkat Konservatisme Akuntansi. Jurnal Ilmiah Mahasiswa FEB Universitas Brawijaya.

Zhang, Jian. (2011). The Effect of IFRS Adoption on Accounting Conservatism - New Zealand Perspective. Doctoral dissertation. Auckland University of Technology. 